\title{
The Relationship of Certain Branched Bacterial Genera
}

\author{
By K. A. BISSE'T AND F. W. MOORE \\ Department of Bacteriology, University of Birmingham
}

SUMMARY: The aerobic sporing Streptomyces may be distinguished from the parasitic anaerobic Actinomyces by the type of branching which they possess. It is proposed that they should be assigned to separate orders, Streptomycetales and Actinomycetales. The latter order is subdivided according to the type and arrangement of the component cells, and consists of two Families. The first, Actinomycetaceae, includes anaerobic actinomyces, and also 'soil diphtheroids' for which a new genus, Jensenia is proposed. The second, Mycobacteriaceae, includes Mycobacterium, Corynebacterium and Nocardia.

The true relationship of those bacterial genera which have, at various times, been grouped with the Actinomyces, is not easy to establish. In most early classifications the character of branching, however occasional, has been given great weight, although the techniques employed for the definition of this character have not always been adequate to the task; many genera, having little else in common, have been classed together for this reason. More recent amendments of the original schemes have been based largely upon the original, inadequate evidence (Waksman \& Henrici, 1943). A return to the primary basis of classification, morphology, and a re-examination of the evidence in this respect, might remove some of the anomalies of the present position.

The name Actinomyces was originally given to the filamentous organism which was responsible for actinomycosis in animals; later the fungus-like organisms, now often called Streptomyces, were included in the genus. The present classification of Bergey (1948) restores the distinction between the two groups but retains them in a single order.

Lehmann \& Neumann (1896) proposed the genera Corynebacterium and Mycobacterium, primarily for the pathogenic bacteria causing diphtheria, tuberculosis and leprosy. Later the genus Corynebacterium was extended to include almost any Gram-positive, non-motile, non-sporing bacterium showing any morphological irregularity; and the genus Mycobacterium to include any acid-fast organism.

As indicated by Conn \& Dimmick (1947), each genus had species assigned to it which differed more from other species in the same genus than did the type species from one another. The classification of Bergey (1948), which limits the genus Mycobacterium to $\boldsymbol{M}$. phlei, $\boldsymbol{M}$. lacticola and the usual pathogens, appears to be sound, but the separation of Corynebacterium from Mycobacterium, and the introduction of the family Corynebacteriaceae into the Eubacteriales is unjustifiable, in view of the close morphological resemblance between the type species of the two genera (Bisset, 1949). The present genus Nocardia is heterogeneous; Umbreit (1939) divides the genus (alternatively called Proactinomyces) into $\alpha$ and $\beta$ forms, the former resembling corynebacteria and the latter forming a stable mycelium, but without spores. Umbreit suggested that the acid-fast 
and non-acid-fast $\alpha$-Proactinomyces might be related to Mycobacterium and Corynebacterium respectively, and also related, via the $\beta$-Proactinomyces, to Streptomyces. Jensen (1934) suggested a similar relationship, regarding the various intermediate forms as evidence that these genera form a natural group.

Biochemically the streptomyces, actinomyces, mycobacteria and corynebacteria are well defined, whereas the nocardia, as at present defined, are heterogeneous, but can be divided into two rather ill-defined sub-groups, one of which resembles the mycobacteria in being non-proteolytic, and failing to produce acid from sugars. The second group resembles the streptomyces, being proteolytic and able to hydrolyse starch. It is probable that these two subgroups are not closely related.

\section{MATERIALS AND TECHNIQUE}

Morphological examinations were made by Gram's method and by Robinow's (1945) tannic acid violet stain for cell-walls. Preparations made by the latter method are of such value in the elucidation of the morphology of bacteria, and the technique is so simple to perform, that any morphological study which fails to make use of it, and thus fails to determine whether the organism described is composed of one cell or many, must be regarded as incomplete.

The following strains of bacteria were examined:

Pathogenic actinomyces. Eight newly isolated strains, two from human, and six from bovine infections, all were anaerobic on isolation.

Other parasitic organisms. Two non-sporing, actinomyces-like organisms from the human mouth, aerobic and apparently non-pathogenic. Four sporing actinomyces (Streptomyces) from the healthy mouths of laboratory animals.

Soil 'diphtheroids' and nocardia. Thirty strains of these organisms were isolated from soil, and six strains of Gray \& Thornton's (1928) Proactinomyces were obtained from the National Collection of Type Cultures.

Streptomyces. Thirty-one strains were isolated from soil and water, in addition to the four from animal sources mentioned above.

\section{OBSERVATIONS}

The pathogenic actinomyces were grown anaerobically upon nutrient agar containing $1 \%$ glucose. The colonies were adherent to the medium and consisted of radiating filaments (Pl. 1, fig. 1), in which little or no branching was observed. This contrasted strongly with the appearance of the aerobic, sporing organisms (Streptomyces) which branched very obviously (Pl. 1, fig. 2), and in which the branched condition of the component cells, as described by Klieneberger-Nobel (i947), was readily seen.

In smears stained by tannic acid violet the pathogenic forms showed occasional, short branches, which soon became separated from the main stem. This type of branching is more accurately described as budding (Pl. 1, figs. 3, 4). The strains from human and bovine sources, including the two aerobic strains from the normal human mouth, were alike in this respect, but differed in that the filaments of the human strains were invariably much longer than 
in the bovine strains. The component cells were also of great length in the human strains (Pl. 1, figs. 5, 6). The constancy of this difference throughout several weeks of culture suggests that this species may be subdivided into human and bovine types analogous to those of $\boldsymbol{M}$. tuberculosis. On sub-culture the anaerobic character progressively diminished, and disappeared after a few weeks. The colonies also tended to become less adherent.

A more complete examination of the morphology of the sporing strains was not attempted, as these organisms have already been competently described (Klieneberger-Nobel, 1947).

The soil bacteria and proactinomyces were of two major morphological groups. Those corresponding to the general description of 'soil diphtheroids', branched only occasionally and the branch was separated from the parent cell (Pl. 1, fig. 7). In some strains the cell-wall was highly irregular, and produced a fallacious appearance of branching in a Gram-stained film (Pl. 1, fig. 8). These bacteria were unicellular, and quite distinct from the true corynebacteria, which are multicellular (Bisset, 1949). In the early stages of growth all the strains of this group produced an unstable mycelium which later fragmented into bacillary forms. Surface colonies on Lemco agar were pinkish, glistening and easily emulsified.

The second type consisted of more filamentous organisms, and formed surface colonies on Lemco agar which were white, waxy and difficult to emulsify. The filaments were frequently branched and were composed of numerous very short cells. They bore a general resemblance to the branching mycobacteria described by Brieger \& Fell (1945). As with all other forms observed, except streptomyces, the mature branch was separated from the parent filament, and the component cell was not branched (Pl. 1, fig. 9). By Gram's method, the shrunken cell contents formed Gram-positive granules in the Gram-negative filament (Pl. 1, fig. 10).

\section{DISCUSSION}

We have attempted to discover a series of morphological criteria by which the various types of branched bacteria might be classified. There is no real justification for the present habit of confining morphological examination to Gramstained, heat-fixed preparations, especially as the tannic acid violet technique, which reveals the cell boundaries, is simpler than Gram's method to perform.

We consider that the sporing aerobic Streptomyces are entirely distinct from the other organisms described, and propose a separate Order, Streptomycetales, for them, retaining the Order Actinomycetales to include the remainder of the groups under discussion. The character of acid-fastness is widely distributed in both orders, and, unless pronounced, is not of great importance. Bacteria of the 'soil diphtheroid' type have not, in the past, been well described, and individual species have been assigned to various genera, especially Corynebacterium, Mycobacterium and Nocardia. A new genus, Jensenia, is proposed to include the aerobic, unicellular bacteria of this type.

The two orders are defined as follows. 


\section{Order STREPTOMYCETALES}

Filamentous, branching bacteria. (Their position in the Schizomycetes is assumed but is questionable.) Mature branch continuous with parent stem. Cell branched. Spores formed (Fig. 1).

There is one family, Streptomycetaceae, consisting of two genera, Streptomyces and Micromonospora, defined as in Bergey (1948).

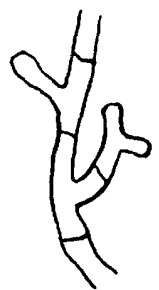

Fig. 1. Streptomyces.

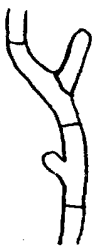

(a)

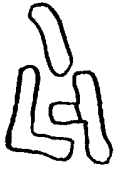

(b)

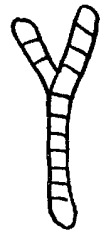

(a)

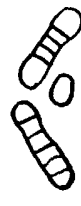

(b)

Fig. 3. (a) Nocardia, (b) Mycobacterium and Corynebacterium.

\section{Order ACTINOMYCETALES}

Filaments or rods, sometimes branched. The mature branch is divided from the parent filament by a partition. Cell unbranched. Spores not formed.

Two families are described, which are distinguished by the length of the cells comprising the bacillus or filament.

\section{Family I. Actinomycetaceae}

Cells several times as long as broad. Individual bacillus unicellular.

\section{Genus A. Actinomyces}

Filamentous, often anaerobic or microaerophilic. Animal parasites and pathogens (Fig. 2a).

\section{Genus B. Jensenia}

'Soil diphtheroids'. Aerobic, short, often irregular in shape, occasionally branched (Fig. 2b).

Family II. Mycobacteriaceae

Breadth of cells approximately the same as length. Individual bacillus is multicellular.

\section{Genus C. Mycobacterium}

Strongly acid-fast. Occasionally branched (Fig. $3 b$ ).

\section{Genus D. Nocardia}

Slightly or non-acid-fast. Filamentous, often branched (Fig. 3a).

\section{Genus E. Corynebacterium}

Non-acid-fast. Short, unbranched. Animal parasites and pathogens (Fig. 3b). 
In this classification no effort has been made to accommodate the various genera (e.g. Erysipelothrix) of which adequate morphological descriptions are not available, and which we have not examined. We consider that the criteria of types of branching and types of cell are sufficiently clear-cut to make allocation to families relatively easy, once these genera are properly described.

The greatest defect of the proposed system is that the characters defining the various groups are relative, that is to say, they may sometimes lie within the limits of variability of a single species at various ages and conditions of culture. Very small corynebacteria may often consist of a single cell; aged cultures of actinomyces are sometimes composed of multicellular, bacillary forms; in the initial stages, all branches may be alike, and so forth. Nevertheless, we consider that the scheme approximates more closely to the true relationship of the bacteria, and is more readily applicable to the description of new genera and species, and the rearrangement of those already recorded, than those now in general use.

\section{REFERENCES}

Bergey, D. H. (1948). (Edited by Breed, R. S., Murray, E. G. D. \& Hitchens, A. P.) Manual of Determinative Bacteriology, 6th ed. London: Baillière, Tindall and Cox.

Bisset, K. A. (1949). Observations on the cytology of Corynebacteria and Mycobacteria. J. gen. Microbiol. 3, 93-6.

Brieger, E. M. \& FELL, H. B. (1945). Warm-stage observations on the initial development of the avian tubercle bacillus cultivated in embryo extract. $J$. Hyg., Camb., 44, 158-69.

ConN, H. J. \& Dimmick, I. (1947). Soil bacteria similar in morphology to Mycobacterium and Corynebacterium. J. Bact. 54, 291-303.

Gray, P. Н. Н. \& Thornton, H. G. (1928). Soil bacteria that decompose certain aromatic compounds. Zbl. Bakt. (Abt. 2), 73, 74-96.

JENSEN, H. L. (1934). Studies on saprophytic Mycobacteria and Corynebacteria. Proc. Linn. Soc. N.S.W. 59, 19-61.

Klieneberger-Nober, E. (1947). The life-cycle of sporing Actinomyces as revealed by a study of their structure and septation. J. gen. Microbiol. 1, 22-32.

Lemmann, J. \& Neumann, R. (1896). Atlas und Grundriss der Bakteriologie, 1 st ed. Munich: Lehmann. Cited by Conn \& Dimmick (1947).

Robinow, C. F. (1945). Addendum to The Bacterial Cell by R. J. Dubos, Cambridge, Mass., U.S.A.: Harvard University Press.

Umbreit, W. W. (1939). Studies on the Proactinomyces. J. Bact. 38, 73-89.

Waksman, S. A. \& Henrici, A. T. (1943). The nomenclature and classification of the Actinomycetes. J. Bact. 46, 337-41.

\section{EXPLANATION OF PLATE}

Fig. 1. Actinomyces bovis, edge of colony on agar, unstained. $\times 350$.

Fig. 2. Streptomyces sp., edge of colony on agar, unstained. $\times 350$.

Figs. 3, 4. A. bovis, budding and separation of branches. Tannic acid violet. $\times 3000$.

Fig. 5. A. bovis, bovine type, typical short filaments. Tannic acid violet. $\times 3000$.

Fig. 6. A. bovis, human type, typical long filaments. Tannic acid violet. $\times 3000$.

Fig. 7. Jensenia sp. bacillary forms and small branch. Tannic acid violet. $\times 3000$.

Fig. 8. Jensenia sp. showing irregular outline. Tannic acid violet. $\times 3000$.

Fig. 9. Nocardia sp. multicellular, branched filament. Tannic acid violet. $\times 3000$.

Fig. 10. Nocardia sp. granular appearance by Gram's stain. Granules are shrunken cell contents. $\times \mathbf{3 0 0 0}$.

(Received 26 November 1948) 
Journal of General Microbiology, Vol. 3, No. 3
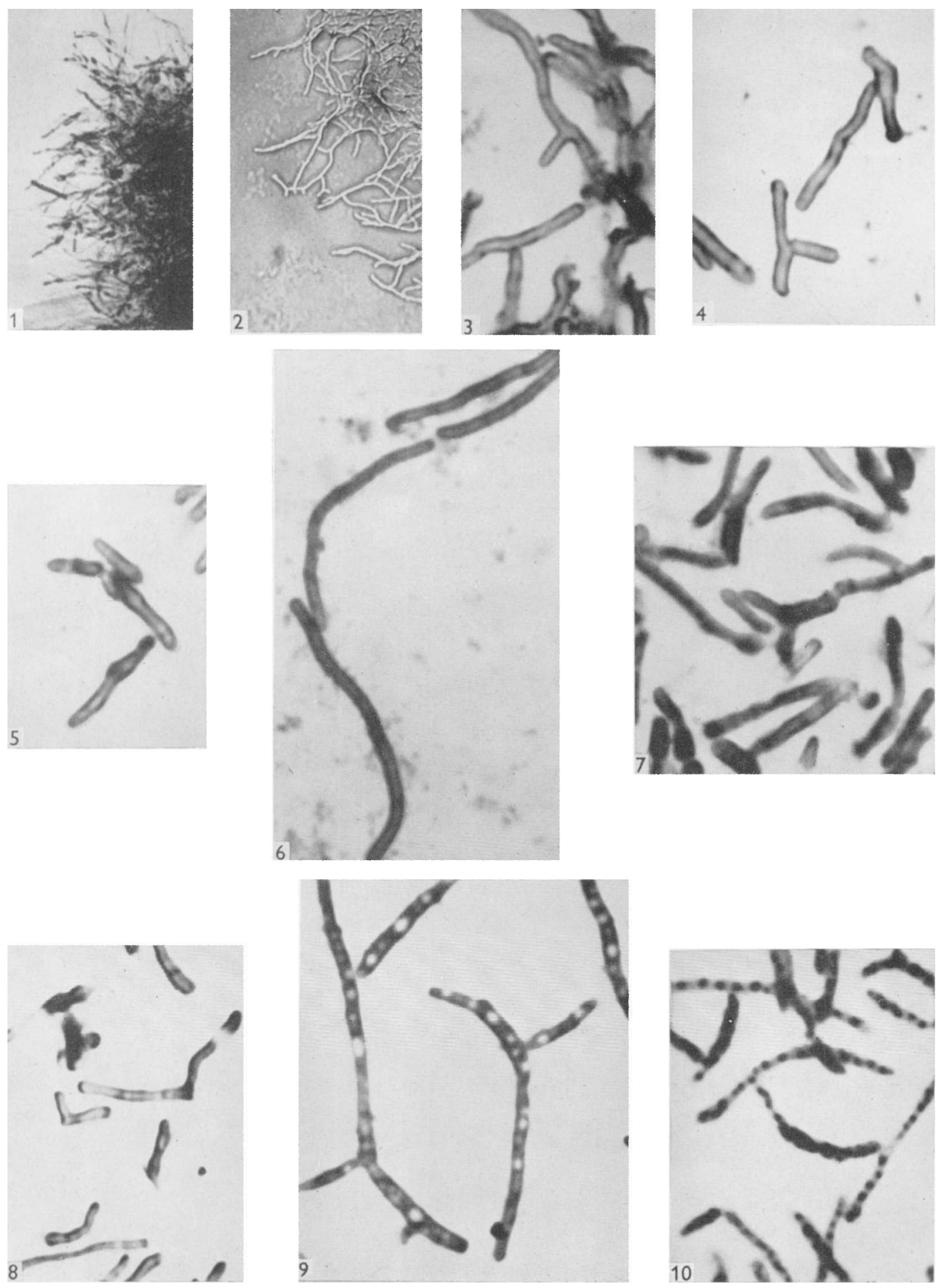

Figs. 1-10

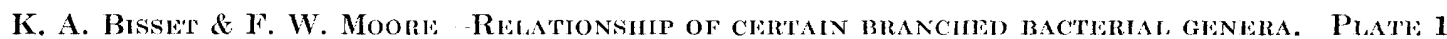

